\title{
UM OLHAR SOBRE A CONSTRUÇÃO DAS IDENTIDADES FEMININAS : OS "CAUSOS" DE ASSOMBRAÇÃO EM CALDAS, MINAS GERAIS
}

\author{
Marcelo Elias Bernardes ${ }^{1}$ \\ Sabrina Melo Del Sarto
}

\begin{abstract}
RESUMO: A proposta deste artigo assenta-se em uma análise da formação social da mulher caldense sob o prisma das narrativas de assombração, prática difundida do município mineiro de Caldas e que também se configura como uma crença religiosa popular. Ao adentrarmos na dimensão das práticas e representações coletivas, observamos a construção da mulher enquanto uma idealização edificada sobre preceitos religiosos e que possui um discurso capaz de fornecer elementos que naturalizam uma concepção subordinada, que atuam sobre seu corpo e reprimem suas vontades. Nesse sentido, a primeira parte deste trabalho procura elucidar estes contos populares e os comportamentos considerados desviantes, observados a partir da noção de pecado e protagonizados por mulheres que transgrediram as normas sociais sendo consideradas assombrações que vagam no mundo dos vivos. Na segunda parte, por meio das narrativas de assombração, procuramos evidenciar alguns aspectos das cotidianidades de nossas narradoras. A metodologia utilizada é a história oral combinada com a observação participante, essenciais para o desenvolvimento das pesquisas de campo, uma vez que a crença na existência das assombrações permeia as relações sociais e se debruça exclusivamente sobre a tradição oral.
\end{abstract}

Palavras-chave: Tradição. Religiosidade. Cotidiano.

\section{SITUANDO 0 CAMPO E A QUESTÃO}

O município de Caldas, localizado na região Sul do Estado de Minas Gerais, possui alguns aspectos que devemos enunciar antes de entrarmos na discussão central deste trabalho, uma vez que não apenas contribuem na ilustração da localidade na qual estudamos, como também atravessam questões que emergem das relações sociais e das representações coletivas. Caldas possui uma

1 Marcelo Elias Bernardes é Doutorando em Ciências Sociais pela Universidade Estadual Paulista (UNESP), campus de Marília. Mestre (2018) e bacharel (2016) em Ciências Sociais pela mesma universidade. Licenciado em História (2010) pelo Centro Universitário da Fundação de Ensino Octávio Bastos. Email: eliasbernardesm@gmail.com

2 Sabrina Melo Del Sarto é Doutoranda em Antropologia Social pela Universidade Federal de Santa Catarina. Mestra também em Antropologia Social pela mesma universidade. Bacharela em Ciências Sociais (2017) pela Universidade Estadual Paulista (UNESP). Email: sabrinadelsarto@hotmail.com 
população distribuída entre a cidade e dezenas de pequenas comunidades rurais, espalhadas pelo território, fundadas em laços de parentesco e que totalizam mais da metade de sua população . Nesse sentido, e por meio de nossas vivências, entendemos que a ruralidade é uma característica que não pode ser pensada exclusivamente a partir da espacialidade. A entendemos como uma forma de pensamento ligado ao campo, expressa na linguagem e nos ditados populares como modo de vida e presente na agricultura de subsistência que na contemporaneidade não é fechada como em décadas atrás.

Desta maneira, ao considerarmos esta agricultura familiar para o consumo próprio, o que aponta, segundo Antônio Candido em Parceiros do Rio Bonito (2001), para uma cultura rústica, marcada por uma sustentabilidade em vários níveis, conforme veremos a seguir, inserimos Caldas dentro uma perspectiva caracterizada por Candido (2001) e Carlos Rodrigues Brandão (1980;1985) como cultura caipira.

Plantava de tudo. Era arroz, feijão, amendoim, milho, inhame, cará, abobrinha. A gente vinha de vez em quando para a cidade. O porco que ele [pai] matava, punha na garupa do cavalo e trazia para vender na cidade num "restaurantinho" onde hoje é a Chups [sorveteria do benzedor Paulinho]. [...] Galinha ele vendia no Norinho [venda] perto do Botafogo, perto do campo [de futebol]. [Maria Ferreira, 10/10/2017, 60 anos, moradora da parte urbana].

Outro aspecto relevante é a presença do catolicismo desde o início da colonização da região e que pode ser observada hoje nas inúmeras propriedades e imóveis pertencentes a Igreja Católica ao longo de toda a extensão territorial do município. Neste contexto, observamos que a maioria dos bairros rurais possuem uma capela ou uma igreja - referências que demarcam o centro das comunidades - e alguns deles estão localizados ao lado de um centro comunitário que também pertence à esta instituição religiosa. Não obstante, a área urbana possui diversas edificações como casas nas quais realizam aulas de catecismo e crisma e o ponto que nos fornece maior referência de sua visibilidade é conjunto de três praças que demarcam o centro da cidade, onde estão localizados tanto o seu núcleo histórico quanto comercial e consequentemente é o local de maior mobilidade de pessoas e automóveis. Este conjunto de praças, tratado pela população unicamente como "a praça" é delimitado por duas igrejas, a Matriz, localizada no mesmo ponto onde foi erguida a primeira capela do arraial na segunda metade do século XVIII pelos colonizadores portugueses, e a do Rosário, construída no início do século XX por ex-escravos, membros da irmandade que carrega o mesmo nome da igreja.

Esta presença do catolicismo circunscreve, obviamente, não apenas a questão espacial e alcança também uma predominância no que se refere ao número de fiéis em relação às demais instituições religiosas. Nesse sentido, em face da proposta deste artigo, é importante ressaltar que o catolicismo é um agente que contribui na confecção das visões de mundo, das práticas e, consequentemente, das identidades coletivas. Entretanto, há que se refletir sobre a epistemologia deste catolicismo caldense que é tecido, de um ponto de vista histórico, de forma horizontal entre seus adeptos em suas cotidianidades, sobretudo porque o contato com o clero e com o culto público, como as missas, mesmo atualmente, é algo que está distante de ser pleno e que se relaciona, em sentido estreito, com nosso período colonial (MOTT, 1997). Dentre estes aspectos podemos apontar a extensão territorial do município, mesmo passando por processos de fragmentações e de emancipações políticas desde o final do século XIX, além da precariedade das estradas de terra, o número reduzido de padres para atender a demanda religiosa das comunidades rurais e de forma menos aguda hoje, 
as dificuldades nos meios de transporte. Entendemos que estas dificuldades para o exercício de um catolicismo oficial, em seu sentido público, aliadas com a convivência com a população escrava e ameríndia da região contribuíram para que ocorressem convergências e apropriações culturais e religiosas com suas cosmovisões, nas dimensões das práticas e das representações, processo este que tomamos a partir da noção de hibridismo cultural .

Nesse sentido, a figura de benzedeiras e benzedores, responsáveis pela cura de determinadas doenças, dentre as quais, algumas provém de um campo espiritual, como os feitiços e os mau olhados, se constituiu a partir de aproximações com determinados referenciais simbólicos das etnias nativas da região, como Hélio "Bugre", neto de uma índia com quem aprendeu o ofício de benzer. Presenciamos seu rito de cura que envolve o uso de plantas locais, a performance de descosturar o corpo, retirar a moléstia, costurar o corpo ao mesmo tempo que ele profere versos mágicos. Atrelado aos benzedores, porém não exclusivamente de forma direta e paradoxal, como observou Ginzburg em Os Andarilhos do Bem (1978), encontramos as práticas de feitiçaria, entendidas, por uma parcela da população, como resultados de raiva e inveja e traduzidas a partir de uma ótica demoníaca, muitas vezes ligada com a cor da pele.

Estas formas híbridas que exibem a manifestação de um mundo espiritual na cotidianidade caldense, muitas vezes desconhecida e contingente, é também presente em práticas usadas para controlar ou mandar embora tempestades ou chuvas fortes, que podem danificar as residências. Este rito doméstico consiste em queimar folhas de coqueiro, sacralizadas apenas durante a missa de Domingo de Ramos, normalmente em uma panela velha e sendo ainda acompanhado por rezas católicas. Tais interações entre o mundo espiritual e o mundo material podem ser vistas ainda através da devoção aos santos católicos a partir de relações de reciprocidade e troca (BRANDÃO, 1985; SÁEZ, 2009) e da aparição de assombrações que, em certa medida, são almas penadas de caldenses já falecidos.

Mediante tais complexidades, trabalhamos com uma noção de cultura dinâmica que se aproxima de Geertz (1989), entendida como um sistema de símbolos transmitidos, compartilhados e interpretáveis, capazes de fundamentar uma compreensão de mundo e abertos às ações e interesses dos agentes (SAHLINS, 1990). Assim, nossa proposição metodológica, construída entre a teoria antropológica, as vivências em campo com a população caldense e a história local, no permite pensar neste catolicismo como um sistema simbólico e que, em virtude de sua pluralidade, dinamismo e criatividade, adicionamos a categoria popular (PORTO, 2007).

Neste contexto, considerando a predominância histórica do catolicismo enquanto parte do projeto colonizador português (PIERRE SANCHIS, 1995) e, portanto, de sua influência em Caldas que alcança até mesmo a esfera do poder público, o percebemos como um dos elementos centrais que pincelam a identidade coletiva. Porém na dinâmica das relações sociais, este sentimento de pertencimento, mesmo que possua convergências simbólicas com outras cosmologias, alterizam as pessoas e os grupos religiosos menores que não possuem as mesmas referências e produzem, não raras vezes, um olhar, a priori, que diferencia, inferioriza e isola os fiéis pertencentes às outras religiões, sejam pentecostais, neopentecostais ou afrobrasileiras.

Em virtude disto, trabalhamos com a noção de estigma traçada por Erving Goffman, entendida como " a situação do indivíduo que está inabilitado para a aceitação social plena" (2012, p.4). Nesta obra, ele procurou analisar diversas formas pelas quais as pessoas são estigmatizadas, passando por aspectos que atravessam as deformidades do corpo, os desvios de caráter e o pertencimento às religiões menores em relação à uma dominante. Em Caldas, tomando estas perspectivas em um 
sentido lato, observamos que a identidade de grupo possui outros atributos que balizam as diferenças e em muitas ocasiões, dialogam com fundamentos do catolicismo popular local. Nesse sentido, existem intersecionalidades que exibem formas como o outro é percebido e categorizado a partir de concepções socialmente pré-determinadas e idealizadas, como a mulher. Desta forma, umas das problematizações que trataremos a seguir gravita em torno da intersecção entre a representação da mulher, alicerçada em práticas normativas e as assombrações, que espelham seus desvios e consequentemente mostram as punições divinas.

Ao considerarmos este contexto e a cultura, esta como ponto de partida para nosso trabalho, não podemos negligenciar a presença do poder nestas relações sociais que se apresentam para além da vida cotidiana material e alcança níveis espirituais mais amplos ao evidenciar noções ligadas ao pecado, ao sofrimento da alma, ao castigo e à purgação - estigmas que acompanham a memória destas mulheres após a morte. Ao evidenciarmos o poder, não propomos delineá-lo em uma diretriz exterior, acima da cultura ou da história. Ao contrário, o inserimos dentro de uma historicidade específica que fornece força aos significados (COMAROFF; COMAROFF, 2010).

Assim, o poder é uma qualidade intrínseca do social e do cultural; em resumo, sua capacidade de determinação. Às vezes ele aparece como capacidade (relativa) dos seres humanos de moldarem a vida dos outros, através do controle sobre a produção, circulação e o consumo de signos e objetos, sobre a formação tanto das subjetividades quanto das realidades. (COMAROFF; COMAROFF, 2010)

Por fim, ao considerarmos poder e cultura como esferas inseparáveis, seguindo a perspectiva de Jean e John Comaroff, não podemos também ignorar a agência dessas caldenses, enquanto capacidade de ação mediada por seus interesses, desejos e pessoalidades em face de uma lógica social normatizadora que pretende controlar as subjetividades e as formas de comportamento. Nesse sentido, as construções das identidades também passam por este crivo que contém elementos que permeiam as relações sociais e o imaginário - as assombrações - e, portanto, as tecituras destas identidades são balizadas também nas relações entre os vivos e os mortos.

Texto do artigo. As normas para elaboração dos artigos estão disponíveis no endereço eletrônico da revista movimentação. Antes de qualquer submissão, os/as autores/as devem preencher todos os campos do perfil solicitados adequadamente, sob pena dos trabalhos serem devolvidos/ arquivados. Portanto, tenha certeza de que o Perfil contenha as informações imprescindíveis para o processo de avaliação e edição dos originais, caso forem aceitos].

\section{NARRATIVAS DE ASSOMBRAÇÃO E CATOLICISMO POPULAR: DISCURSOS QUE ESSENCIALIZAM AS MULHERES CALDENSES}

Ao considerarmos o catolicismo popular como um sistema simbólico aberto e dinâmico que amalgama práticas e representações complexas, presentes na cotidianidade da população caldense, que foram e são (re)produzidas de forma relativamente afastadas da doutrina católica, interpretamos que as assombrações não apenas fazem parte deste campo semântico como também agenciam as sociabilidades, uma vez que as pessoas procuram benzedores, benzedoras e os párocos locais para expulsá-las das residências, benzer estas ou quando entendem que estão sendo acompanhadas por espíritos.

Há que se ponderar também que a categoria local assombração é complexa, em termos de sentidos e formas de existência - algumas são dotadas de materialidade corporal - e, portanto, ela 
pode ocultar inúmeras variações que estão atreladas ainda às interpretações dos agentes e às diversas historicidades que se acumulam na memória coletiva. Desta maneira, ao nos defrontarmos com "causos" sobre corpo-secos, lobisomens, almas de antigos moradores que vagam pelo município e bichos, devemos considerar que mesmo em virtude das explicações que os sujeitos fornecem, desenvolvidas por meio de suas experiências ou apreendidas através da oralidade, as interligações entre o mundo espiritual e o mundo material não são plenamente conhecidas (BRANDÃO, 1985), como podemos observar na narrativa que o retireito (cuidador de sítio) Vinícius nos contou vivenciada por sua família em uma roça próxima ao distrito rural Santana de Caldas.

Ela [sua mãe] estava lá na casa da minha avó, na casa velha. O que que aconteceu? [pausa] o meu avô tinha saído e ele foi para Santana. Ele foi de caminhão junto com um amigo dele. Aí nisso chegou ela, mais três tias e um tio meu [...] Era até Semana Santa, era Quaresma, então era perto da Semana Santa. Aí eles estavam lá, aí minha avó falou assim "Nós vamos rezar para [pausa], já que a gente está sozinho aqui" e eles começaram a rezar. Passado pouco tempo que eles estavam rezando, [a assombração] começou a bater na lata, na sala, de colocar milho para os porcos. Aí bateu nela. Minha avó era corajosa demais e ela foi lá, pegou a lata, levou e pôs em cima do fogão. E disse assim "Bate agora". Não bateu e voltou a pegar de novo. Nisso, ele [tio] já estava chorando de medo e voltaram a rezar, quando vê, a sela do cavalo ficava lá na sala também dependurada, não sabe o que aconteceu que [a assombração] montou na sela do cavalo e começou a galopar nela. Aí minha avó, lá do quarto, ela falou "Não estou fazendo nada para ninguém e quero que se tiver que fazer alguma coisa que venha e faça aqui. Ela foi lá e pegou a sela do cavalo, levou e pôs em cima do fogão também. Aí passado pouco tempo depois, um cachorro que tinha lá na avó [...] ele assustou tanto que do alpendre ele pulou, passou por cima do chiqueiro de tanto medo que ele ficou. Aí ele saiu latindo para baixo assim [inaudível] e desde aquele dia nunca mais apareceu. E aí nisso, passado pouco tempo depois meu avô chegou e na hora que eles viram a luz do caminhão, desapareceu tudo [...]. (V.T.S., entrevista, 20/03/2012, 28 anos, Caldas)

Isto nos permite pensar que, em Caldas, as pessoas normalmente não estão imunes à qualquer tipo de manifestação, independentemente de suas práticas e religiosidades. Esta condição é imprescindível para refletirmos sobre a profundidade que as assombrações possuem na localidade, sobretudo ao colocarmos em perspectiva também que determinados barulhos, como portas que se abrem, fecham ou passos - chamados de trupés - podem ser vistos como indicadores de que a pessoa está assombrada e, portanto, a crença nas assombrações configura uma visão de mundo que possui referenciais para a compreensão da realidade.

A tradição oral atrelada às religiosidades contribuíram para que estas referências permanecessem na construção de uma identidade coletiva por meio da prática do contar, mesmo que a memória e seus significados possam estar sujeitos à alteração (DELGADO, 2006). No entanto, seus usos ao longo do tempo possibilitaram que estas cosmovisões contidas nos contos permaneçam na contemporaneidade, elucidando-nos sobre a continuidade de discursos seculares que convivem com outras temporalidades no século XXI.

Ao nos debruçarmos sobre estes contos, percebemos que alguns trazem em seu núcleo semântico os modos como as mulheres devem se comportar e a punição em face de suas ações ao se desviarem dos padrões socialmente estabelecidos. Desta maneira, é possível perceber uma 
interseccionalidade que amalgama catolicismo popular, relações de gênero e concepções de sexualidade. Posto que a religiosidade é um dos elementos de distinção social em Caldas, sua interação nos permite pensar sobre a importância do papel social das mulheres na comunidade e nas relações supramundanas e ao considerarmos que algumas narrativas permanecem na contemporaneidade há décadas ou mesmo há mais de um século, somos levados a refletir que a representação da mulher mesmo diante de inúmeras transformações é envolvida por discursos de poder patriarcais que as sufocam em termos de sexualidade e subjetividade. E, uma vez que tais contos, ancorados na oralidade, circulam pelos bairros e podem ser usados como veículos de transmissão de valores morais, somos impelidos a interpretar que a condição social da mulher caldense possui relevância histórica, haja vista que as pessoas transmitem os valores que consideram relevantes para a comunidade (POLLACK, 1992).

A pedagoga aposentada e moradora do distrito rural São Pedro de Caldas, Maria Bruno Franco, nos contou, em sua residência, uma narrativa de assoombração bastante conhecida no bairro e que entendemos ser compartilhada por grande parte da população em virtude de a termos ouvido em diversas ocasiões, inclusive por crianças e adolescentes. Este "causo" proporciona um panorama além da relação próxima entre o mundo dos vivos e o mundo dos mortos ao explicitar a sacralização da maternidade e ilustra uma norma social que controla os corpos das mulheres, rejeitando, em contrapartida, os desejos, interesses e vivências sexuais das mulheres.

[...] nós temos, por exemplo, uma história de uma senhora que chamava Catarina Valera. Ela era sozinha no mundo e parece que ela era louca, não sei. Ela engravidava, engravidava e quando tinha os bebês tomava remédio para abortar (às vezes). Ela enterrava tanto o feto quanto o bebê num brejo que tinha no fundo da casa dela e dizem que depois que ela morreu, passou a aparecer nesse local uma porca acompanhada de vários leitões em determinadas noites e eles acreditavam que ela tinha se transformado numa porca e os filhos em leitões, que a acompanhavam nesse brejo. (Entrevista realizada com Maria Bruno Franco, no dia 04/04/2012. Natural de Caldas. Atualmente mora no distrito de São Pedro de Caldas.)

Esta narrativa comum no distrito rural de São Pedro de Caldas, instiga-nos a utilizar gênero enquanto uma categoria analítica capaz de desvendar o olhar normativo e revelar o sistema social que determinava a posição das mulheres, as determinando ao destino biológico de mães. Assim, Scott (1992) nos mostra as possibilidades que o conceito de gênero fornece ao revelar as relações de poder existentes e como as experiências vivenciadas pelas mulheres em diversos contextos sociais e culturais não podem ser resumidas à categoria reducionista e homogênea identificada como "mulher". Este ponto se configura como emblemático neste artigo, uma vez que compreendemos que a mulher caldense deve ser reconhecida dentro de sua historicidade e seu contexto cultural, o que não impede-nos de posicionar o gênero como capaz de observar e pluralizar a diferença existente entre as mulheres.

A categoria gênero, usada primeiro para analisar as diferenças entre os sexos, foi estendida à questão das diferenças dentro da diferença. A política de identidade dos anos 80 trouxe à tona alegações múltiplas que desafiaram o significado unitário da categoria das "mulheres". Na verdade, o termo "mulheres" dificilmente poderia ser usado sem modificações: mulheres de cor, mulheres judias, mulheres 
lésbicas, mulheres trabalhadoras pobres, mães solteiras, foram apenas algumas das categorias introduzidas. (SCOTT, 1992, p. 87)

O sistema cultural que atua sobre o corpo das mulheres parece ter sido questionado por Catarina Valera nesta narrativa, levando-nos a refletir sobre a agência , o que lhe confere relativa autonomia de ação em contraponto à ideia de heteronomia cultural, que pode ser pensada a partir da perspectiva que atrela o aborto ao pecado. Nesse sentido, observamos a necessidade de inserirmos as mulheres caldenses dentro de um contexto histórico e social, no qual emerge a construção idealizada da mulher, pensada como um espelho da figura sacra de Maria, santidade muito cultuada na localidade, e que foi afrontada pelas atitudes da pessoa no conto que resistiu e transgrediu a norma. É importante também evidenciar, a partir da fala de dona Maria, sobre a categoria louca utilizada para se referir à Catarina Valera. Primeiramente, podemos apontar uma estigmatização social que ela experimentou durante a vida e não apenas após a morte, o que nos leva a pensar, consequentemente, pelo modo literal como dona Maria se expressou, que o significado louco possui tonalidades sociais ligadas às representações e às práticas convencionadas e, portanto, se tece como um indicativo de distanciamento do que é entendido como normal e que não pode ser pensado de forma indissociada de seu sentido patológico.

Assim, uma vez que estes "causos" carregam em sua estrutura visões de mundo, valores e formas de comportamento, procurando ainda transmitir mensagens de castigo sobre aqueles que transgridem as normas sociais e religiosas, somos levados a pensar em sua importância histórica para a (re)produção de um modelo de mulher e de um catolicismo popular em Caldas, que foi construído de forma coletiva entre várias perspectivas cosmológicas. Devemos também incluir na discussão a categoria do medo na medida que esse sentimento permite a permeabilidade dos valores morais presentes nas narrativas, sobretudo quando consideramos que a prática do contar se inicia durante a infância atuando, portanto como um ensinamento social que adquire uma roupagem na religiosidade popular e cuja eficácia tem a potencialidade de agenciar as pessoas.

Vislumbrar este sistema simbólico que engendra práticas e representações religiosas a partir da perspectiva de gênero corresponde a adquirir um novo olhar sobre a realidade caldense, muitas vezes indisponível aos olhos da população, permitindo-nos observar as hierarquias implícitas entre os sexos. Catarina Valera é a personagem que transita oralmente pela memória coletiva da população, sendo repreeendida por exercer liberdade sobre seu corpo e sua sexualidade. Piscitelli (2002) argumenta que a opressão e a subordinação das mulheres e as relações de poder que perpassam por este sistema de determinação sexual estão presentes em todos os aspectos da vida social.

Considerando que as mulheres eram oprimidas enquanto mulheres e que suas experiências eram prova de sua opressão, se chegou à conclusão de que a opressão feminina devia ser mapeada no espaço em que as mulheres a viviam, isto é, nas suas vidas cotidianas. (PISCITELLI, 2002, p.5)

Desta forma, entendemos que a dominação masculina apresenta-se em Caldas tanto na esfera pública quanto nos ambiente doméstico, no qual a educação familiar reproduz a construção cultural das categorias feminino e masculino. Esta perspectiva não apenas reprime a construção das subjetividades desde a infância, como também naturaliza estas relações desiguais na vida cotidiana local. Tal situação ganha profundidade à medida que a religiosidade é um elemento relevante na 
cultura local, no resguardo da identidade coletiva e contribuiu, neste aspecto da dominação, para a formação mais sólida de uma visão de mundo, cujo discurso adquire uma tonalidade aguda ao ser interpretado como pecado.

Outra característica comum das narrativas de assombração é o apontamento de mulheres pecaminosas que pagam por seus erros cometidos em vida ao se tornarem almas penadas que vagam no mundo dos vivos, transmitindo um discurso que se propõe a manter uma ordenação social. $\mathrm{Na}$ narrativa a seguir observamos a explicitação do pecado na prostituição, que coloca-nos questões além do controle sobre o corpo, revelando-nos a necessidade da mulher em conter vontade enquanto desejo sexual.

Ela chamava Ana do Zé Jonas. Ela era uma pessoa [...] como posso dizer [...] tinha uma vida irregular [...] depois que ela morreu, alguns carros que desciam para Pocinhos [distrito de Caldas], principalmente os táxis, ela descia de carona até a casa dela. Sentiam também o banco do carro afundar como se alguma pessoa estivesse lá. O carro podia pisar fundo no acelerador que ela iria junto até chegar na casa. Quando chegava lá, aquilo aliviava e a pessoa iria junto até chegar na casa. Teve uma época [...] que ninguém queria descer para Pocinhos com medo da Ana do Zé Jonas [risadas] [...] Ela era de programa [garota] como se fala hoje. Não pagava nada nas caronas. ( Entrevista realizada com Cibele Zétula Lima, musicista, no dia 03/01/2015. Natural de Caldas. Atualmente mora na área urbana do município)

A narrativa de Ana envolve uma conexão hermética de seus elementos o que garante a eficácia da (re)produção normativa dos valores e costumes locais. A estrada onde eram cometidos seus pecados, as pessoas envolvidas na trama - os motoristas - e a sua casa mostram uma combinação de elementos que estavam envolvidos no âmbito da produção do pecado. A partir deste princípio emerge outro ponto de reflexão, a imagem idealizada da mulher delicada, doméstica, destituída de sexualidade e que não deixa de estar ligada à Virgem Maria. Nesse sentido, a noção de mulher para a população se configura como uma identidade fundamentada em práticas disciplinadoras capazes de determinar a construção do corpo em um processo de internalização de normas que se inicia com a educação religiosa no núcleo familiar.

Nestes contos é perceptível a agência das mulheres, as formas como pensavam e agiam diante das possibilidades que a cultura e seus significados dominantes forneciam em determinadas circunstâncias. Elas não se comportavam como reprodutoras do sistema simbólico, o que expressa o seu interesse na ação em relação ao discurso de poder em sua cultura. Sahlins (1990) aprofunda a discussão ao informar que os agentes fazem sua própria interpretação da cultura e que sua ação é envolvida por um interesse individual. Assim, Catarina e Ana possuíam interpretações distintas acerca dos padrões culturais locais, o que lhes forneceu uma posição no campo social de inferioridade, estigma e rejeição em um jogo de luz e sombra acerca do pertencimento e da aceitação na identidade coletiva local. Portanto, as mulheres caldenses que não se submeteram às regras sociais são posicionadas no campo como desviantes ao lado de diversos agentes que se guiam por outras referências simbólicas, como homossexuais, fiéis umbandistas, evangélicos ou qualquer outro grupo ou pessoa que se afastam das práticas dominantes entendidas como naturais, verdadeiras e universais (COMAROFF; COMAROFF, 2010).

Por outro lado, não podemos deixar de elucidar que a agência de nossas narradoras está em profunda articulação com o lugar do seu discurso em um processo que envolve a memória e a 
identidade coletiva e individual. O uso das narrativas e as lembranças sobre aquelas mulheres, personagens nos contos, são formas que refletem suas visões de mundo e a permanência destes causos na contemporaneidade nos elucida sobre a importância de seus valores para a comunidade. Assim, entendemos que a memória social está ligada às preocupações do tempo presente (POLLACK, 1992) e, portanto, passa por um processo de seletividade. A narrativa ao ser contada é uma escolha individual que é envolvida por um discurso imerso dentro do jogo das relações de poder entre visões de mundo diferentes e que informa-nos sobre a subjetividade da pessoa que narra.

Nessa dimensão, na qual a ação do imaginário e da memória são responsáveis pela manutenção de uma tradição que desenha o perfil de agentes excluídos e estigmatizados por determinadas práticas que fogem aos padrões de comportamento, localizamos outro "causo", vivenciado pela senhora Sebastiana no bairro rural Bom Retiro. Esta narrativa elucida um caso incomum que se desdobrou na separação de uma família. O marido desta mulher era um lobisomem, contudo, ela não tinha consciência disso. Certa noite ele saiu, voltou para a casa - transformado na criatura - e tentou atacar seu filho “(...) ele pulou para pegar a criança, que é filho dele mesmo e ela subiu numa árvore de medo.” E continua sua narrativa “(...) Aí diz que ele subia e arranhava, (ela) olhava e via aqueles fiapos nos dentes dele, daquele bicho ali, cachorro, (...)". Até o momento ela não desconfiava, porque o marido tinha o costume de sair pela noite. Contudo, passado o ocorrido, já pela manhã, "Aí diz que ela viu aqueles fiapos de pano nos dentes dele e que (...) o tipo (...) não sei bem o que era isso, aquelas saias de baeta, (...)”. Ela acabou encontrando nos dentes dele os fiapos de sua própria saia rasgada pelo lobisomem e "Ela separou, nunca mais quis saber dele" (Entrevista realizada com Sebastiana Ribeiro Borges, aposentada, no dia 31/07/2012. Natural de Caldas, atualmente mora na parte urbana do município).

Este conto coloca em evidência como a noção de agência pode ser vivenciada pela esposa ao optar pelo divórcio, amparando-se sobre os pressupostos da tradição recorrente e utilizando, portanto, as representações acerca da figura do lobisomem, para justificar essa ruptura matrimonial que durante expressivo período era considerado um tabu social em face da legitimidade dada por Deus e protocolada pela Igreja Católica. Dessa forma, ao recorrer às práticas da sua cultura, baseando-se em seus interesses e desejos, entendemos a partir da ótica de Sahlins (1990), que as pessoas colocam a cultura em ação, o que retira a possibilidade de pensarmos o sistema simbólico como algo estático e os agentes como meros reprodutores dos significados culturais. Tal condição, nos permite pensar na possibilidade de utilização da crença local como justificativa para buscar o divórcio diante de uma possível infelicidade de viver sob o mesmo teto e que serviu como arcabouço para amenizar as pressões sociais, inclusive de seus pais que poderiam conceber a separação, sob outras circunstâncias, como algo inaceitável que envolveria questões que atravessam valores sociais, como a desonra da família e o constrangimento diante da comunidade.

Estas marcas sociais são instrumentos que amordaçam as mulheres além de buscarem naturalizar suas posições dentro de um sistema social e reproduzirem um discurso de inferioridade assentado sob padrões biológicos, noção esta que torna homogênea e culturalmente desqualifica todas as mulheres. Na contemporaneidade em Caldas ainda permanece um imaginário que gravita em torno de uma divisão sexual das relações sociais, tanto em questões pertinentes ao trabalho quanto ao prazer e as perspectivas de vida. É justamente nas entrelinhas da cotidianidade e nos atos corriqueiros que percebemos a permanência do modelo hierarquizado e opressor que inferioriza a mulher. 
O seguinte "causo" nos fornece informações precisas sobre esta crença reducionista de pensamento em que atua como suporte para uma hierarquia que é dada a priori (SCOTT, 1992). Em uma sexta-feira, próxima ao fim de semana, havia o planejamento de cantar modas de viola noite adentro no bairro conhecido como "Ponte do João do Teodorinho", uma pequena comunidade rural de Caldas. Nosso narrador Joaquim Venâncio, nos relatou um acontecimento que se passou com seu vizinho ao voltar para sua casa após o dia de trabalho.

Chegou no mata burro, diz que tinha uma mulher de branco do outro lado e ele tirou o chapéu e começou a rezar. Diz que [ela] desapareceu. Aí ele foi em sua casa, alguns metros para cima, aí veio o irmão dele e o amigo começou a buzinar o jipe [para saírem] e ele não foi. Aí o irmão dele foi lá. [o vizinho disse] "Não vamos, chama o Argentino Lemes, chama ele para cá porque aconteceu isso comigo, assim [...] e a minha mulher ficou nervosa [...] Vamos trazer eles para cá, nós jantamos e cantamos moda e faz aqui fora e tal." Foram para lá. Chegaram, e o Argentino era meio "loucão" [o vizinho então disse]"Argentino é meio assombrado lá e a mulher não quer ficar sozinha, vamos lá para a casa?" [Argentino disse] "Que jeito era a assombração?" "Uma mulher de branco"[respondeu o vizinho] [Argentino] "Assombração de mulher? Eu não tenho medo não, aparece de novo aí!" Quando vê apareceu [...] já não era de branco mais, era uma coisa escura, uma preta [...] aquilo foi crescendo e diz que foram afastando. Entraram no jipe, deram partida, manobraram. Dizem que amanheceram tomando café e ninguém deitou de medo [...] Isso foi pertinho da minha casa e eu passava [por ali] e graças a Deus nunca vi nada não. ( Entrevista realizada com Joaquim Venâncio da Fonseca, lavrador aposentado, no dia 06/06/2015. Natural de Caldas, atualmente mora na parte urbana do município)

Existem alguns pontos que apreendemos desta narrativa e que não podem ser omitidos, uma vez que esboçam as relações de poder nos pequenos detalhes da vida cotidiana. Novamente nos deparamos com uma forma de pensamento em que a mulher plural está reclusa e destinada à vida doméstica, em um contexto em que não havia possibilidade de sair para diversão, como seu marido deveria fazer constantemente. Percebe-se isto quando nosso narrador lembrou que a esposa do seu vizinho não queria ficar sozinha, o que indica que ele iria apenas com os amigos.

Há que se considerar historicamente que as "boas mulheres" caldenses eram aquelas que saiam apenas para participar de celebrações públicas religiosas, como as missas, as novenas e as festas de santos da comunidade e que seu papel social está ligado às atividades relacionadas à maternidade. Entretanto, observamos que houve modificações nesta condição social das mulheres e isto pode ser melhor pensado se colocarmos em perspectiva a noção de geração de Sirinelli (2002), sobretudo porque cada uma possui características próprias, construídas por experiências e são demandas de seu tempo histórico. Nesse sentido, as novas gerações, ainda que possuam experiências distintas e peculiares em relação às antigas, não podem ser pensadas em torno de um momento de ruptura e tão pouco a partir de uma cronologia.

Mesmo que ocorreram transformações na forma de pensar e agir das mulheres de uma geração mais recente, ainda identificamos a presença de um discurso ofensivo em relação àquelas que frequentam bares pela noite ou desejam se casar tardiamente. Este discurso não está presente apenas no universo masculino à medida que as mulheres mais velhas também olham para as mais novas com este olhar dominante, delineando conflitos a partir de visões divergentes entre as gerações 
diferentes das mulheres locais, o que nos permite uma aproximação teórica com a noção de Lucília Delgado (2006) de dinâmica da temporalidade, em que múltiplas perspectivas entrecruzam-se em uma mesma comunidade. Assim, consideramos que a nova geração retém traços de um pensamento misógino, ainda que tenha superado outros pontos a partir de novas vivências e representações, muitas proporcionadas pelos avanços dos meios de comunicação de massa, e que estão relacionados, por exemplo, com o número crescente de mulheres frequentando as universidades em cidades vizinhas.

Outro ponto que não podemos deixar de destacar se refere à posse da mulher enquanto uma propriedade masculina. Nosso narrador, ao parafrasear seu vizinho na narrativa mostra-nos a presença de uma heteronormatividade sexista e compulsória, na qual a mulher enquanto um objeto de pertencimento do universo masculino, passa do pai para o marido, o que nos mostra a permanência do patriarcalismo na cidade. Além disso, é evidente nesta narrativa a inferiorização da mulher plural em um sistema que a idealiza ao mesmo tempo em que a exclui. No fim do conto, o homem chamado Argentino se referiu com deboche sobre as assombrações de mulheres e as desafia, o que nos revela novamente a fragilidade e a passividade que circunscrevem o mundo das representações locais, que estão presentes em várias cenas da vida cotidiana e que emergem aos nossos olhos através do uso da ferramenta gênero, capaz de nos fornecer lentes para pensar as relações de poder (PISCITELLI, 2002).

\section{HISTÓRIAS DE VIDA E TEMPORALIDADES ENTRE AS MULHERES CALDENSES}

Optamos por utilizar a terminologia mulheres caldenses não apenas pelo recorte proposto neste trabalho, o que já exigiria comumente este olhar, todavia, também por entendermos que existem diferenças e peculiaridades culturais que unicamente podem ser vislumbradas em seu campo histórico de formação. Partindo de tal opção analítica procuramos evitar aproximações com conceitos que perpetuam generalidades, como a ideia universal de mulher, evitando, com isso, cair em armadilhas etnocêntricas que podem simplificar a pluralidade.

Nesse sentido, a discussão de Marlise Matos (2010) torna-se relevante ao dialogar com Chandra Mohanty (1984) acerca do reducionismo expresso pela perspectiva dada às mulheres do terceiro mundo enquanto uma categoria monolítica e estável. Mohanty ainda identifica nos debates feministas do Norte global um discurso colonizador que suprime as complexidades das mulheres que não estão inseridas no contexto estadunidense e europeu. Ao criticar esta visão simplista, na qual as mulheres latino americanas são entendidas como domésticas, religiosas e sexualmente limitadas, Matos aponta a superficialidade contida na proposta de Nancy Fraser (2007).

Ponto crítico e limitante no artigo é a espécie de reducionismo, a partir do Norte global, ao qual Fraser submeteu a discussão dos feminismos no mundo, associando-os a parâmetros e experiências exclusivas aos do movimento norte americano, como é sobejamente conhecido, opera por meio de um enquadramento exclusivamente liberal e capitalista [...] (MATOS, 2010, p. 73)

Ao considerarmos a diversidade que a categoria mulheres implica, nos colocamos no sentido de defender uma observação acerca da multiplicidade de vivências e contextos e entendemos que tais teorias as reificam na mesma proporção que as pretendem emancipar (BUTLER, 2003). Assim, nosso ponto de ancoragem atrelou-se às mulheres caldenses e suas distintas experiências, muito ligadas à vida religiosa e rural como fruto do contexto em que estão inseridas, mas que não devem 
ser tomadas e entendidas dentro deste espectro monolítico homogeneizante, coeso e apartado da história, como se tempo não proporcionasse transformações e como se as contradições sociais não produzissem comportamentos distintos, os quais evidenciamos nas narrativas de assombração.

O tempo é um movimento de múltiplas faces, características e ritmos, que inserido à vida humana, implica em durações, rupturas, convenções, representações coletivas, simultaneidades, continuidades, descontinuidades e sensações [a demora, a lentidão e a rapidez]. É um processo em eterno curso e em permanente devir. (DELGADO, 2006, p.10)

Ao nos propormos analisar as memórias vivas destas mulheres, tanto àquelas representadas nos contos - já falecidas - quanto nossas narradoras, devemos estar atentos às suas experiências e temporalidades diferentes. Muitas viveram grande parte de sua vida em pequenas comunidades rurais, onde experienciaram a vida no campo, em um momento histórico no qual hospitais, escolas e mercados eram mais acessíveis à população da área urbana.

Rosa contou-nos um "causo" de assombração que ela vivenciou e que é capaz de ilustrar alguns elementos de sua vida cotidiana na área marginal da cidade, próxima ao bairro Santa Cruz.

Nós fomos buscar lenha, aí eu estava [...] aí eu fiz o meu feixe de lenha e a minha companheira [vizinha] estava amarrando o dela e eu escutei um barulho, só que achei que era ela. Aí fui acompanhando aquele "trupé" [passos], pensando que era ela. E eu fui descendo mato abaixo. Na hora que eu olhei, assim, juro por Deus, aí eu vi ela com a blusa verde [longe]. Aí eu falei "Margarida, olha o 'trupé', eu estava acompanhando o 'trupé'. Depois eu não consegui colocar o feixe de lenha na cabeça, ela que colocou [...] Eu já tinha arrumado minha lenha. Já tinha amarrado. (Entrevista realizada com Rosa Elisa do Nascimento, cuidadora de idosos, no dia 06/01/2017. Natural de Caldas. Atualmente mora na área urbana do município)

A importância da história oral e da observação participante reside na possibilidade de termos acesso à memória, à visão de mundo e à cotidianidade destas mulheres, permitindo-nos uma aproximação com suas experiências de vida. As lembranças tal como Delgado (2006) afirma, são suportes das identidades coletivas e fornecem ferramentas de reconhecimento do ser humano no mundo. Sebastiana trouxe-nos algumas de suas memórias quando morou no Bom Retiro, muitas permeadas pelo medo que tinha de um senhor que era considerado lobisomem pela comunidade porque ela ficava em casa sozinha com os filhos pequenos.

$\mathrm{Na}$ roça, muitas vezes, eu via o lobisomem, via. Tinha mesmo. Eu tinha medo do homem que era lobisomem [...] Eu já era casada, tinha dois filhos. Tinha o Zé Painha e o outro que morreu, o João, e ele [o lobisomem] gostava de pedir as coisas [...] as coisas não são fáceis não. Eu morria de medo. Só que eu tinha dó do velhinho porque ele ia. Muito pobre o coitado né? Eu arrumava umas coisas para ele [...] só que depois ele não ia mais porque eu falava [para ele] "Eu tenho medo" e o Zé Painha meu era pequenininho [...] e a gente deitava, trabalhava o dia inteiro. Deitava, dormia e pegava café na talha [do fogão de lenha] [...] Eu fazia cesta [de palha], levava comida para ele [marido] trabalhar na roça. Assim, trabalhava na roça. Ele pegava empreita de pasto para roçar, juntava alguns camaradas. Tinha que fazer comida sabe. (Entrevista realizada com Sebastiana 
Ribeiro Borges, aposentada, no dia 31/07/2012. Natural de Caldas, atualmente mora na parte urbana do município)

Essas cotidianidades fortemente marcadas pelas representações coletivas colocam em plano de fundo as dificuldades da vida nas áreas rurais, sobretudo para as mulheres que tinham que cuidar do lar, dos filhos e trabalhar em casa para contribuir com a renda. Em muitas ocasiões encontramos relatos da confecção manual das cestas de palha feitas pelas esposas e as filhas, uma vez que os meninos ao atingirem determinada idade acompanhavam o pai nas lavouras, o que nos revela a presença de uma divisão sexual do trabalho que permanece na contemporaneidade em Caldas.

A distância do pequeno centro urbano também representava vários impedimentos à vivência religiosa dos ritos públicos, favorecendo práticas de improviso, limitadas aos ambientes domésticos. Nesse contexto, entendemos que os contos de assombração ao se configurarem enquanto uma crença tornaram-se vivos na memória coletiva e fazem parte integrante da vida cotidiana. Assim, estas narrativas são formas de um ensinamento popular costurado pelos fieis em seu catolicismo e que ainda possui convergências com elementos das tradições culturais indígenas e africanos. Dona Maria nos contempla com suas lembranças da infância e que nos elucidam sobre esta discussão.

Durante a infância [...], à noite meu pai sentava na taipa do fogão. Nós, os filhos todos sentávamos em volta. Alguns momentos ele ia nos ensinar a rezar. Nos outros momentos depois que ele ensinava, ele ia contar as histórias, casos de assombração do tempo que ele era moço, que saía muito [...] e é lógico que nós tínhamos um medo terrível, mas os momentos mais gostosos que tínhamos era quando ele contava as histórias [...]. (Entrevista realizada com Maria Bruno Franco, no dia 04/04/2012. Natural de Caldas. Atualmente mora no distrito de São Pedro de Caldas)

A religiosidade, em seus desdobramentos pelas cotidianidades das pessoas, se configura como um aspecto importante da vida social. Esta colocação se releva durante a realização das festas anuais no município, sejam nos bairros rurais - devotadas aos santos padroeiros das localidades - ou na cidade, como a Festa do Arraial e a Festa de Nossa Senhora do Patrocínio. Observamos, tanto nas festas realizadas na cidade quanto nos bairros São Pedro de Caldas e Santo Antônio, uma intensa mobilização dos moradores em todo o processo que envolve sua confecção. Neste contexto, sua participação é indispensável, seja através da mão-de-obra ou por meio das doações de prendas para os bingos, como frangos, porcos e doces, o que contribui para a arrecadação financeira da Igreja Católica. Cibele nos disse que desde a adolescência participou da coleta destas doações passando por várias comunidades. Anos mais tarde, quando se tornou musicista disse-nos que não deixava de participar dos eventos religiosos, sempre tocando sem cobrar qualquer tipo de bonificação. Em uma de nossas conversas ela contou sobre uma experiência que chamou de "paranormal" ao encontrarem uma velhinha cega na beira da estrada na entrada da cidade e que segundos depois desapareceu.

Nós fomos arrecadar prenda, eu e o senhor Zé Lambreta e a filha dele a Vera. Fomos de jipe para pegar lá para o lado do Maranhão [bairro rural], na região. Estávamos vindo, quase seis horas da tarde, o jipe lotado de prendas como leitoa, galinha. Foi quando na nossa frente, perto de uma igrejinha, perto do Zumiro [hoje um posto de gasolina]. [...] Então tinha uma ceguinha que andava com uma bengalinha e nisso estava começando a chuviscar. Nós vimos a Patrocínia na nossa frente pelo acostamento, quase perto da igrejinha. Foi assim que eu falei "Seu Zé, vamos dar uma 
carona para a Patrocínia? [...] Seu Zé encostou o carro, fui chamar ela e cadê a Patrocínia? Não tinha Patrocínia nenhuma, procurei dentro da igrejinha e nada. O pior foi é que nós três vimos, porque se fosse só eu ou ele ou somente a Vera [...] era impossível ela estar naquele lugar, naquele horário, naquele dia chuvoso [...] Ela morava na Vila [asilo municipal], logo depois ela morreu [...] Foi uma aparição para falar, falar para a gente "Ela vai morrer" [...] O Zé assustou tanto que em dois segundos ele estava na cidade, ficou com mais medo do que nós [...]. (Entrevista realizada com Cibele Zétula Lima, musicista, no dia 03/01/2015. Natural de Caldas. Atualmente mora na área urbana do município)

Estas cenas da vida cotidiana presente nas memórias de nossas narradoras nos permite entender como as práticas e as representações constroem a realidade vivida. Terezinha, disse-nos que viveu toda sua vida no centro urbano e ouviu muitos "causos" de seu pai que sempre trabalhou nas fazendas que se localizavam às margens da cidade. Ela trouxe uma narrativa muito conhecida na cidade e que carrega um discurso que determina outra norma de comportamento que as mulheres devem seguir.

Ele gostava de se mudar e cada lugar que ele ia via algo diferente, uma história diferente, uma coisa estranha diferente. Tipo abria a porta e via o bode preto altas horas da noite, via mula sem cabeça. Tudo aqui na cidade, tudo por aqui em volta [...] A mulher de branco era uma mulher que saia do cemitério e ia para os bailes. Então ela tinha tal hora para chegar no baile e hora para sair do baile. Então quando ela ia já avisava o parceiro dela que meia noite tinha que sair do baile e certa vez um dos apaixonados dela resolveu seguí-la. Então ela saiu do baile e foi terminar o baile no cemitério [risos]. É uma história estranha e engraçada, mas ela ia para o baile tipo nove ou dez horas, só que meia noite ela tinha que ir embora e ninguém sabia porque. (Entrevista realizada com Terezinha Aparecida Paes, salgadeira, no dia 08/11/2016. Natural de Caldas. Atualmente mora na parte urbana do município)

Esta história nos permite pensar uma outra dinâmica social presente na vida das pessoas da parte urbana do município, como os bailes que eram mais constantes do que nas áreas rurais, entretanto esta narrativa é relevante em outras duas perspectivas. A primeira revela-nos uma forma correta de agir direcionada às mulheres devendo portanto, permanecer no ambiente doméstico pela noite, o que transpassa novamente pela noção idealizada da mulher que deve zelar por um perfil reservado. A segunda se configura ao mostrar o lugar do discurso de nossa narradora em relação à sua apropriação dos contos de assombração, mostrando-nos uma resignificação de sentido fornecida por ela enquanto uma agente que faz uso particular de sua cultura. Assim, temos acesso à outra interface destas histórias - a diversão e o entretenimento - que são outras formas de apropriação que as pessoas fazem da cultura popular local.

\section{APONTAMENTOS FINAIS}

Durante nossa convivência com a população caldense, observamos que as narrativas de assombração que colocam em perspectiva algumas mulheres consideradas pecadoras permanecem em suas cotidianidades e reproduzem discursos que pretendem tornar homogêneas as formas de pensar e de agir. Desta maneira, estes causos se comportam como suportes e veículos de determinados valores sociais filtrados pelo catolicismo popular local. Algumas narrativas ainda nos 
mostraram a presença do patriarcalismo, como no primeiro causo que trouxemos neste trabalho. Nele, o momento da chegada do pai de caminhão em sua casa, marcou o fim do tormento de uma assombração e renovou a temporalidade da segurança do lar.

Olhar para a memória e o lugar do discurso de nossas narradoras, enquanto elementos indissociáveis, contribuíram para que observássemos estes outros olhares para os contos de assombração, o que evidencia a noção da agência das mulheres caldenses em muitos aspectos. É necessário, entretanto, compreendermos que a memória não é um local no qual se guardam lembranças imodificáveis, mas sim um processo que se transforma com o tempo (PORTELLI, 1999). Em face desta colocação, entendemos que o discurso que gravita em torno da representação e da identidade da mulher caldense é muito presente em nossas narradoras e que acabam reproduzindo as concepções culturais que reprimem as subjetividades e mesmo considerando a memória como um movimento contínuo, entendemos que suas modificações ainda carregam determinados elementos permanentes que são considerados fundamentais para as relações na comunidade.

A cultura popular, em sua circularidade, exerce papel importante na construção da identidade coletiva ao mesmo tempo que demarca as diferenças e a alteridade, mostrando-nos as propriedades e a eficácia do seu discurso entre as pessoas. Os contos de assombração enquanto parte integrante de um universo, particularizado como de Caldas, associado à religiosidade (re)cria estigmas sociais que refletem as formas comportamentais inaceitáveis dentro sistema simbólico local, o que nos leva a pensá-los como mantenedores de um discurso de poder, no qual as ações que fogem do padrão são observadas sob a ótica do pecado e passivas de uma punição que transcende o plano material. Os "causos" de assombração ao adquirirem o caráter de verdade e ao projetarem os comportamentos desviantes, contribuem para a dinâmica das relações sociais, revelando-se como instrumentos que naturalizam a mulher, reprimem desejos e controlam seu corpo.

Entretanto, há que se considerar também que estes discursos de poder ligados à cultura e ‘religiosidade não podem ser pensados hoje sob o prisma de uma hegemonia que marcou a temporalidade de gerações anteriores, ao contrário, há um processo histórico em Caldas, no que se refere à emancipação da mulher em sentido lato. Identificamos um aumento gradativo de divórcios no município bem como uma opção pela continuidade dos estudos no ensino superior mesmo que em Caldas não exista qualquer tipo de universidade. Evidenciamos ainda que as mulheres, em certa medida, estão postergando o casamento, o que não implica em supor a inexistência de uma vida sexual como em décadas atrás. Deste modo, se os causos de assombração podem ser vistos como discursos de poder normatizadores e que contribuem na tecitura de uma identidade coletiva, não podemos afirmar que o processo de emancipação das caldenses se confronte diretamente e em todos os aspectos com determinados valores que permanecem hoje, sobretudo porque os atributos que balizam a identidade coletiva, constróem e demarcam as diferenças se moficam na esteira do tempo e não permanecem os mesmos.

\section{REFERÊNCIAS}

BRANDÃO, Carlos Rodrigues. Memória do Sagrado: estudos de religião e ritual. São Paulo: Ed. Paulinas, 1985.

. Os deuses do Povo: um estudo sobre a religião popular. São Paulo: Brasiliense, 1980. 
BUTLER, Judith. Problemas de gênero: feminismo e subversão da identidade. Tradução, Renato Aguiar. Rio de janeiro: Civilização Brasileira, 2003.

CANDIDO, Antonio. Parceiros do Rio Bonito. 9. ed. São Paulo: Saraiva, 2001.

COMAROFF, J; COMAROFF, J. "Etnografia e imaginação histórica. PROA - Revista de Antropologia e Arte [on-line], ano 02, vol. 01, n. 02, nov. 2010: 1-72.

DELGADO, Lucilia de Almeida Neves. História Oral e narrativa: tempo, memória e identidades. Belo Horizonte: Autêntica, 2006.

FRASER, Mapeando a imaginação feminista: da redistribuição ao reconhecimento e à representação. Revista Estudos Feministas, v. 15, n. 2, p. 291-308, 2007.

GEERTZ, Clifford. A interpretação das culturas, Rio de Janeiro: Ed. Guanabara, 1989.

GINZBURG, Carlo. Os andarilhos do bem: feitiçarias e cultos agrários nos séculos XVI e XVII. São Paulo: Companhia das Letras, 1988.

GOFFMAN, Erving. Estigma: notas sobre a manipulação da identidade deteriorada. 4. ed. Rio de Janeiro: LTC, 2012.

MATOS, Marlise. Movimento e Teoria Feminista: é possível reconstruir a teoria feminista a partir do Sul global? Social Político, v.18, n. 36, p. 67-92, 2010.

MATOS, Raimundo José da Cunha. Corografia histórica da Província de Minas Gerais (1837). Belo Horizonte: Editora Itatiaia; São Paulo: Editora da USP, 1981.

MOHANTY, C. T. 1984. Under Westerns Eyes:Feminist Scholarship and Colonial Discourses. Boundary 2, Durham, v. 12, n. 3, p. 333-358.

MOTT, Luiz. Cotidiano e vivência religiosa: entre a capela e o calundu. In: NOVAIS, Fernando (coord.). História da vida privada no Brasil. Vol. 1. Cotidiano e vida na América Portuguesa. São Paulo: Companhia das Letras, 1997.

ORTNER, Sherry. Poder e Projeto: Reflexões sobre Agência. In: Grossi, M.; Eckert, C; Fry, P. Conferências e Diálogos: Saberes e Práticas Antropológicas. Blumenau: Editora Nova Letra, 2006. P. 45-80.

PIERRE SANCHIS, J.F. As tramas sincréticas da história. Sincretismo e modernidades no espaço luso-brasileiro. Revista Brasileira de Ciências Sociais, 28, p.123-138, 1995.

PIMENTA, Reynaldo. O povoamento do planalto da Pedra Branca - Caldas e região São Paulo: Rumograf, 1998. Obra póstuma.

PISCITELLI, Adriana. Recriando a (categoria) mulher? In: ALGRANTI, L. (org). A prática feminista e o conceito de gênero. Textos didáticos, n. 48, p. 7-42, 2002. 
POLLACK, Michael. Memória e Identidade Social. Estudos Históricos, n.5, v.10, p 200-212, 1992.

PORTELLI, Alessandro. Tentando aprender um poquinho. Algumas reflexões sobre História Oral. In: Proj. São Paulo, n. 15, p. 13-49, 1999.

PORTO, Liliana. A ameaça do outro: magia e religiosidade no Vale do Jequitinhonha (MG). São Paulo: Attar, 2007.

SÁEZ, Oscar Calavia. Fantasmas Falados: mitos e mortos no campo religioso brasileiro. Campinas: Editora da Unicamp, 1996.

SAHLINS, Marshall. Ilhas de História. Rio de Janeiro: Jorge Zahar, 1990.

SCOTT, Joan. História da Mulheres. In: A escrita da história. Novas Perspectivas. São Paulo, Ed da Unesp, 1992, p. 62-95.

SIRINELLI, Jean-François. A geração. In: FERREIRA, Marieta de Moraes. AMADO, Janaína. Usos e abusos da História Oral. 5.ed. Rio de Janeiro: Editora da FGV, 2002. 